\section{THE DYNAMICS OF PHYSICAL DEVELOPMENT OF G-YEARS-OLD CHILDREN IN LVIV}

\author{
Fedorenko V.I., Kitsula L.M.
} ДИНАМІКА ФІЗИЧНОГО РОЗВИТКУ 6-РІЧНИХ ДІТЕЙ М. ЛЬВОВА

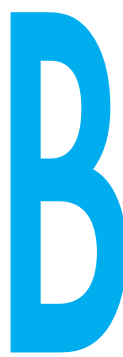

ФЕДОРЕНКО В.І., КІЦУЛА Л.М.

Львівський

національний медичний

університет

ім. Данила

Галицького

УДК: $613.954616-$

071.3-

053.4(477.83)

Ключові слова:

фізичний

розвиток,

динаміка, маса

тіла, зріст, діти

6-річного віку,

антропометричні

індекси. ідомо, що фізичний розвиток є критерієм здоров'я дітей і надалі визначає стан здоров'я людини у різні періоди її життя. Рівень і темпи фізичного розвитку залежать від значної сукупності факторів - генетичних, індивідуальних морфо-функціональних особливостей організму, вікових фізіологічних змін до впливу на нього довкілля, середовища життєдіяльності, харчування, природно-географічних і соціальноекономічних умов проживання. Фізичний розвиток дітей наприкінці минулого століття характеризувався зниженням антропометричних показників порівняно з попередніми роками, збільшенням частки дітей, які мали дефіцит маси тіла. Така ситуація спостерігалася в усіх статево-вікових групах дітей не лише в Україні, але й в інших країнах Європейського регіону [1]. Нині процеси інтенсифікації зросту і маси тіла поєднані з астенізацією дітей, дисгармонійним розвитком за рахунок дефіциту та надлишку маси тіла. За дослідженнями Польки Н.С. і співавт., проведеними у 1998-2005 роках, виявлено процеси астенізації у фізичному розвиткові дітей дошкільного і шкільного віку [2]. Серед усіх обстежених в Україні дітей молодшого шкільного віку кожна третя дитина (32,28\% дівчаток та 31,15\% хлопчиків) має дисгармонійний фізичний розвиток за рахунок дефіциту маси тіла, а у решти - майже 67-69\% «дисгармонійних» дітей за рахунок дефіциту обводу грудної клітки та знижених показників життєвої ємності легенів, що свідчить про загальні процеси граціалізації у сучасних дітей шкільного віку [3]. Динамічні спостереження за фізичним розвитком і станом здоров'я дітей і підлітків, які мешкають в одних і тих регіонах, через певні інтервали дозволяють встановити зміни у характері закономірностей фізичного розвитку. Аналіз динаміки антропометричних показників фізичного розвитку дітей дошкільного віку м. Львова та Львівської області проведено нами за 25 років (1969-1996) [4].

Мета роботи - вивчити закономірності динаміки фізичного розвитку дітей 6-річного віку м. Львова за період з 1969 до 2015 року за показниками зросту, маси тіла і обводу грудної клітки та оцінити фізичний розвиток дітей на сучасному етапі.

Матеріали та методи досліджень. Для аналізу динаміки антропометричних показників використовувалися результати, отримані при обстеженні 6-річних дітей у 1969-1971 [5], 1992-1993 та 1995-1996 [6, 7], 20032005 роках [8], а також показники зросту, маси тіла, обводу грудної клітки у дітей, обстежених нами у 20142015 роках. Для оцінки фізичного розвитку сучасних дітей обчислювали індекс маси тіла $\left(\mathrm{I}=\mathrm{MT} / \mathrm{PP}^{2}\left(\kappa \Gamma / \mathrm{M}^{2}\right)\right.$, індекс Піньє (I = ЗР - (МТ + ОГК), пропорційність грудної клітки (ОГК/ЗР) х100\%), де МТ - маса тіла, ЗР - зріст, ОГК - обвід грудної клітки. Антропометричні показники львівських
ДИНАМИКА ФИЗИЧЕСКОГО РАЗВИТИЯ С-ЛЕТНИХ ДЕТЕЙ Г. ЛЬВОВА

Федоренко В.И., Кицула Л.М.

Львовский национальный медицинский университет им. Данила Галицкого

Цель работы: изучить закономерности динамики физического развития детей 6-летнего возраста г. Львова за 1969-2015 годы по антропометрическим параметрам и оценить физическое развитие детей на современном этапе. Материалы и методы исследований. Основанием для анализа динамики физического развития детей послужили результаты антропометрических измерений 1969-1971, 1992-1993, 19951996, 2003-2005, 2014-2015 годов. Для оценки физического развития детей, обследованных в 2014-2015 годах, рассчитывали индекс массы тела, индекс Пинье, пропорциональность грудной клетки, антропометрические показатели детей сравнивали с гигиеническими нормативами 2013 года. Статистический анализ проведен методом наименьших квадратов с определением достоверности результатов по t-критерию Стьюдента. Результаты. Установлено, что динамика физического развития 6-летних детей г. Львова за период от 1969 до 2015 года характеризовалась процессами деселерации и акселерации темпов роста антропометрических показателей. Наиболее низкие значения роста и массы тела детей наблюдались с 1992 по 1996 год, что вероятно связано с нерациональным питанием и поступлением в организм загрязнителей окружающей среды и пищевых продуктов, в частности тяжелых металлов. Наиболее высокие антропометрические показатели отмечались в 2014-2015 годах. Значения индекса массы тела указывают на гармоническое развитие 59,0\% девочек и 55,3\% мальчиков. Индекс Пинье характеризует долихоморфный тип телосложения у 96,9\% девочек и 85,9\% мальчиков, узкая грудная клетка - у 79,7\% девочек и 76,3\% мальчиков на фоне увеличения роста свидетельствует о процессах грациализации. По сравнению с „Критериями оценки физического развития детей Украины" (2013) львовские 6-летние мальчики и девочки выше, имеют большую окружность грудной клетки, а мальчики - и массу тела по сравнению с их сверстниками, что указывает на целесообразность разработки региональных критериев физического развития. Ключевые слова: физическое развитие, динамика, масса тела, рост, дети 6-ти лет, антропометрические индексы.

Федоренко В.І., Кіцула Л.М. СТАТТЯ, 2017. 
дітей, обстежених у 2014-2015 роках, порівнювали з гігієнічними нормативами «Критерії оцінки фізичного розвитку дітей шкільного віку» (2013р.) [9]. Вірогідність відмінностей середніх значень маси тіла, зросту та обводу грудної клітки визначали за t-критерієм Ст'юдента.

Результати та їх обговорення. Фізичний розвиток дітей за основними антропометричними показниками за останні декілька десятиліть зазнав істотних змін і з 1969-1971 до 2014-2015 років. характеризувався періодами уповільнення та зростання темпів росту і розвитку (рис. 1-3).

Протягом 1969-1993 років спостерігалося зниження показників зросту і маси тіла у хлопчиків і дівчаток, зокрема суттєві зміни відбулися у дівчаток. Їхні зріст і маса тіла зменшилися на 1,4 см та 1,19 кг відповідно, хлопчики стали нижчими на 0,8 см, а їхня маса тіла зменшилась у середньому на 1 кг. Наступні виміри зросту і маси тіла львівських 6-річних дітей, проведені у 1995-1996 роках, засвідчили, що антропометричні показники у дітей за 3 роки не змінилися. Після цього зниження зросту і маси тіла за наступні 7 років спостерігалося інтенсивне і практично однакове збільшення темпів росту довжини тіла у хлопчиків і дівчаток, а маси тіла - лише у хлопчиків. Хлопчики підросли на 2,7 см, а дівчатка - на 2,8 см. Тим часом у дівчаток маса тіла не змінилася, а у хлопчиків збільшилася у середньому на $1,1 \mathrm{\kappa г}$ тобто маса тіла у них відновилася до рівня початкового терміну спостереження. Від 2005 року до 2014-2015 рр. продовжувалося зростання антропометричних показників. Більшою мірою це спостерігалося у хлопчиків, які ще підросли на 2,6 см, а темп росту їхньої маси тіла за 12 років становив 1,1 кг. У дівчаток за цей проміжок часу також збільшилася маса тіла на 0,9 кг. Загалом 6-річні хлопчики стали вищими на 4,4 cм, ніж їхні однолітки 46 років тому, водночас маса тіла збільшилася лише на 0,9 кг. 6-річні дівчатка теж стали вищими на 2,1 см, але їхня маса тіла не досягла не лише того рівня, який був на початку відліку динаміки показників, а навіть знизилася на 0,9 кг, тобто на фоні збільшення зросту не відбулося збільшення маси тіла. Обвід грудної клітки теж мав тенденцію до зменшення: у дів-

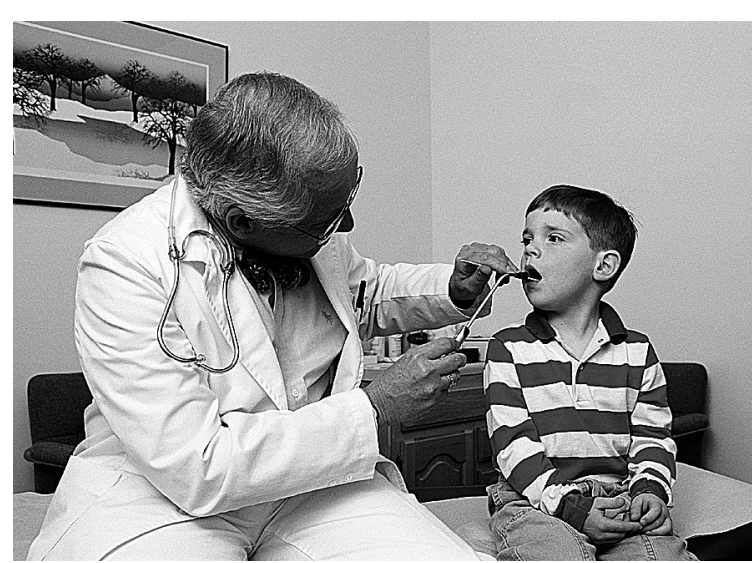

ГІГІЄНА ДІТЕЙ ТА ПІДЛІТКІВ

чаток - на 0,8 см, у хлопчиків на $0,9 \mathrm{~cm}$.

Отримані результати свідчать про поступову зміну акселерації на ретардацію фізичного розвитку дітей наприкінці минулого століття і процеси інтенсифікації зросту, передусім у хлопчиків, у поєднанні 3 граціалізацією на початку нового століття.

Зіставлення антропометричних показників у дівчаток і хлопчиків засвідчило, що 46 років тому зріст і маса тіла у них були однаковими за вірогідно більшого обводу грудної клітки у

хлопчиків, ніж у дівчаток. Надалі простежувалися інтенсивніші темпи збільшення маси тіла у хлопчиків, яка була більшою, ніж у дівчаток протягом усього терміну спостереження. Загалом 3 2003 до 2015 року хлопчики були вищими і мали більшу масу тіла, ніж дівчатка, що є фізіологічно закономірним у цьому віці.

Відомо, що на показники фізичного розвитку дітей неабиякий вплив мають передусім недостатне та незбалансоване харчування і забруднення харчових продуктів та довкілля.

Рисунок 1

\section{Динаміка зросту (см) 6-річних дітей м. Львова (1969-2015)}

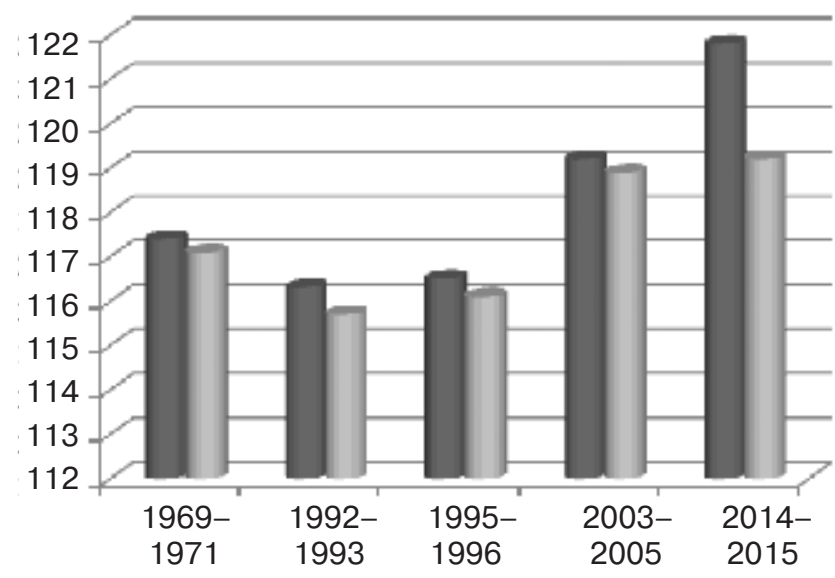

- хлопчики

дівчатка

Рисунок 2

Динаміка маси тіла (кг) 6-річних дітей м. Львова (1969-2015)

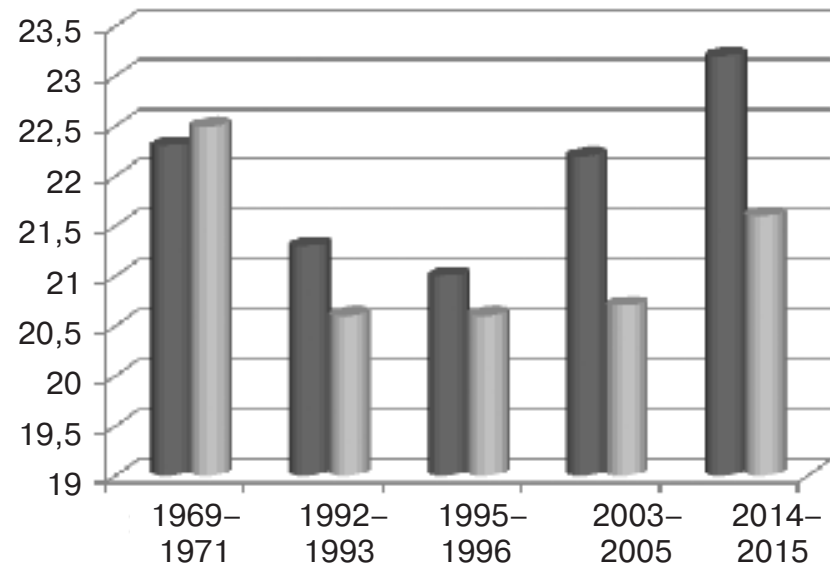

пхлопчики

дівчатка 
Зниження антропометричних показників фізичного розвитку у 1992-1996 роках підтверджується результатами наших досліджень, які отримані за одночасного вивчення фізичного розвитку дітей дошкільного віку (у т.ч. і 6-річних) та їхнього фактичного харчування разом 3 аліментарним надходженням важких металів, зокрема свинцю і кадмію. Тоді було встановлено, що харчування дітей дошкільного віку характеризувалося дефіцитом білка, зокрема тваринного у межах від 20\% до $43 \%$, жирів - від $20 \%$ до $40 \%$ за рахунок недостатнього споживання продуктів тваринного походження, а також складних вуглеводів через недостатне споживання овочів і фруктів. Того часу надходження вітамінів і мінеральних речовин до організму дітей було значно нижчим за рекомендовані норми. Одночасно на фоні дефіциту вітамінів C, B, PP, A, $\beta$-каротину,

Динаміка ОГК (см) 6-річних дітей м. Львова (1969-2015)

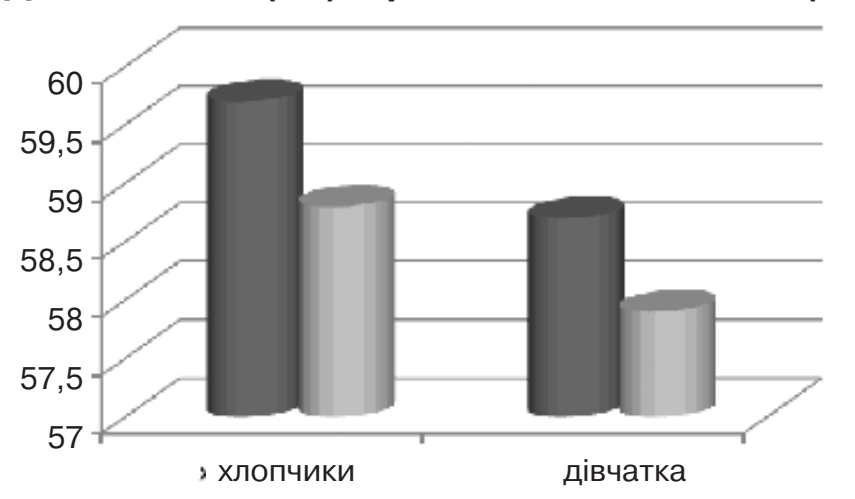

-1969-1971

$=2014-2015$

Таблиця 1

Фізичний розвиток дітей 6-річного віку (\%) м. Львова (2014-2015) за антропометричними індексами

\begin{tabular}{|l|c|c|}
\hline \multicolumn{1}{|c|}{ Показник Індекс маси тіла } & Хлопчики & Дівчатка \\
\hline Виснаження & 5,3 & 4,9 \\
\hline Дефіцит маси тіла & 15,8 & 16,4 \\
\hline Норма & 55,3 & 59,0 \\
\hline Перевищення маси тіла & 10,5 & 13,1 \\
\hline Ожиріння & 13,2 & 6,6 \\
\hline \multicolumn{3}{|c|}{ Індекс Піньє } \\
\hline Вузький (доліхоморфний) тип будови тіла \\
\hline Середній (мезоморфний) тип будови тіла \\
\hline Широкий (брахіморфний) тип будови тіла \\
\hline Пропорційність грудної клітки \\
\hline Вузька \\
\hline Нормальна & 96,9 & 3,1 \\
\hline Широка & 76,3 & 79,7 \\
\hline
\end{tabular}

майже всі антропометричні показники фізичного розвитку дітей дошкільного віку мали тенденцію до зниження, у дітей 6річного віку найбільші зміни стосувалися маси тіла [12].

Отже, процеси ретардації фізичного розвитку дітей дошкільного віку наприкінці XX століття відбувалися у різних регіонах і містах України. Основними причинами цього процесу можна вважати передусім нераціональне харчування дітей і вплив на їхній організм забрудненого довкілля та харчових продуктів, ймовірно, за провідної ролі важких металів.

Значення IMT у $59 \%$ обстежених львівських дівчаток у 20142015 роках коливалися у межах $14,1-16,5$, у $55,3 \%$ хлопчиків - у межах 14,6-16,5, що відповідає нормативним величинам і свідчить про гармонійний розвиток дітей [13]. У решти дітей спостерігалися або надлишок, або недостатність маси тіла різного ступеня (табл. 1), що характеризує дисгармонійність фізичного розвитку дітей.

За індексом Піньє, який дозволяє оцінити міцність будови тіла, встановлено, що більшість дітей $(96,9 \%$ дівчаток та 89,5\% хлопчиків) має доліхоморфний (вузький) тип будови тіла, середній (мезоморфний) мають лише $3,1 \%$ дівчаток та 10,5\% хлопчиків.

Нормальну грудну клітку, за індексом пропорційності грудної клітки, мають 15,8\% хлопчиків та 17,2\% дівчаток, вузьку грудну клітку мають 76,3\% хлопчиків та 79,7\% дівчаток, широку - 7,9\% та 3,1\% відповідно. Розраховані показники свідчать про астенізацію дітей і разом зі збільшенням зросту підтверджують процеси граціалізації.

Порівняльна оцінка фізичного розвитку 6-річних дітей м. Львова, обстежених у 20142015 роках, за антропометричними показниками дітей цієї вікової категорії, наведеними у „Критеріях оцінки фізичного розвитку дітей України" (табл. 2), засвідчила, що львівські 6-річні дівчатка вищі і мають більший обвід грудної клітки на тлі однакової маси тіла, у хлопчиків усі три антропометричні показники вірогідно вищі, ніж значення відповідних середніх показників „Критеріїв”, що свідчить про територіальні особливості фізичного розвитку і доцільність опрацювання регіональних антропометричних критеріїв для дівчаток і 
THE DYNAMICS OF PHYSICAL DEVELOPMENT OF 6-YEARS-OLD CHILDREN IN LVIV

Fedorenko V.I., Kitsula L.M.

Lviv Danylo Halytsky National Medical University

Objective. We studied the regularities of the dynamics of physical development of the children aged 6 years in Lviv city for the period from 1969 to 2015 by the anthropometric parameters and assessed physical development of the children at modern stage.

Materials and methods. The results of the anthropometric measurements in 1969-1971, 1992-1993, 1995-1996, 2003-2005, 2014-2015 were the basis for the analysis of the dynamics of physical development of the children. For the assessment of physical development of the children, examined in 2014-2015, we calculated the body mass index, Pignet's index, proportionality of thorax. The anthropometric indices of the children were compared with the hygienic standards of 2013.

Statistical analysis was carried out by the least squares method with a determination of the authenticity of the results by Student's t-test. Results. The dynamics of physical development of the children aged 6 years in Lviv during the period from 1969 to 2015 was found to be characterized by the processes of decelerations and acceleration of the growth rates of the anthropometric indices.

The lowest values of stature and body weight of the children were observed from 1992 to 1996 that was probably due to the irrational nutrition and the intake of the pollutants from environment and food products, heavy metals in particular. The highest anthropometric indices were observed in 20142015. The values of body mass index indicate the harmonious development of $59.0 \%$ of girls and $55.3 \%$ of boys. Dolichomorphic body type in $96.9 \%$ of girls and $85.9 \%$ of boys is characterized by Pignet's index, the narrow thorax in $79.7 \%$ of girls and $76.3 \%$ of boys with increased growth testifies about the processes of gracialization. In comparison with the Criteria for the Evaluation of Physical Development of the Children in Ukraine (2013) 6-years-old boys and girls in Lviv are higher and have a bigger chest circumference, and boys have a bigger body weight than their peers, that indicates the expediency of the development of regional criteria for physical development.

Keywords: physical development, dynamics, body weight, stature, 6-years-old children, anthropometric indices. хлопчиків різного віку.

Індивідуальна оцінка рівня фізичного розвитку сучасних 6-річних дітей за шкалами регресії [9] показала, що в обох статевих групах переважають діти з середнім ступенем фізичного розвитку за зростом (63,6\% хлопчиків та 73,8\% дівчаток), досить значною $є$ частка дітей зі значенням зросту вище середнього $(24,2 \%$ хлопчиків та 9,8\% дівчаток). Кількість хлопчиків з високим зростом і зростом нижче середнього становила $6,1 \%$ в обох випадках, дівчаток - 9,8\% та 6,6\% відповідно (рис. 4). Слід зазначити, що поміж обстежених дівчаток 4,9\% за показниками зросту виходять за верхню межу для своєї вікової категорії і відповідають зросту дітей 7-8-річного віку згідно 3 „Критеріями оцінки фізичного розвитку дітей України".

\section{Висновки}

1. На основі ретроспективного аналізу і сучасних досліджень антропометричних параметрів фізичного розвитку 6-річних дітей м. Львова 31969 до 2015 року виявлено періоди зменшення та збільшення зросту і маси тіла. Динаміка фізичного розвитку дітей за 46 років характеризувалася деселерацією за зростом і масою тіла у 19921993 та 1995-1996 роках порівняно $з$ 1969-1971 рр., надалі простежувалися чітко акселераційні зміни зазначених показників.

2. Загалом за 46 років найнижчі показники зросту і маси тіла спостерігалися з 1992 до 1996 року, що могло бути пов'язаним 3 недостатнім і нераціональним харчуванням та забрудненням довкілля і харчових продуктів. Найвищі показники зросту і маси тіла хлопчиків, зросту у дівчаток спостерігалися у 2014-2015 рр. Обвід грудної клітки за 46 років практично не змінився.

3. За значенням IMT гармонійний розвиток мали 59,0\% дівчаток і 55,3\% хлопчиків, обстеже- них у 2014-2015 роках. До середнього, вище і нижче середнього ступеня фізичного розвитку за зростом належать 93,9\% хлопчиків і 90,2\% дівчаток. Показники індексу Піньє характеризують доліхоморфний тип статури у 96,9\% дівчаток і 85,9\% хлопчиків, вузьку грудну клітку мають 79,7\% дівчаток і 76,3\% хлопчиків, що на фоні збільшення зросту свідчить про процеси граціалізації сучасних дітей.

4. Порівняльна оцінка фізичного розвитку 6-річних дітей м. Львова, обстежених у 20142015 роках, з антропометричними показниками дітей цієї вікової категорії, наведеними у „Критеріях оцінки фізичного розвитку дітей України”, засвідчила, що 6-річні діти м. Львова випереджають своїх одноліток за усіма показниками, окрім маси тіла у дівчаток, яка практично є однаковою. Зазначене свідчить про територіальні особливості фізичного розвитку і доцільність опрацювання

Порівняльна оцінка фізичного розвитку 6-річних дітей м. Львова з „Критеріями оцінки фізичного розвитку дітей України" [9]

\begin{tabular}{|c|c|c|c|c|c|c|c|c|}
\hline \multirow{2}{*}{ Показник } & \multicolumn{2}{|c|}{$M \pm m$} & \multirow{2}{*}{ 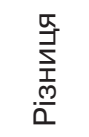 } & \multirow{2}{*}{$\begin{array}{c}t \\
(p)\end{array}$} & \multicolumn{2}{|c|}{$M \pm m$} & \multirow{2}{*}{$\begin{array}{l}\stackrel{\underline{a}}{\vec{J}} \\
\stackrel{\underline{T}}{\underline{m}} \\
\stackrel{\underline{a}}{2}\end{array}$} & \multirow{2}{*}{$\begin{array}{c}t \\
(p)\end{array}$} \\
\hline & \begin{tabular}{|c|}
$2014-2015$ \\
pp.
\end{tabular} & $\begin{array}{c}\text { Критерії } \\
2013 \text { р. [9] }\end{array}$ & & & \begin{tabular}{|c|} 
2014-2015 \\
pp.
\end{tabular} & $\begin{array}{c}\text { Критерії } \\
2013 \text { р. [9] }\end{array}$ & & \\
\hline \multicolumn{5}{|c|}{ Хлопчики } & \multicolumn{4}{|c|}{ Дівчатка } \\
\hline Зріст, см & $122,3 \pm 0,84$ & $118,8 \pm 0,41$ & $+3,5$ & $\begin{array}{c}3,76 \\
(p<0,001)\end{array}$ & $119,2 \pm 0,50$ & $117,5 \pm 0,48$ & $+1,7$ & $\begin{array}{c}2,45 \\
(p<0,02)\end{array}$ \\
\hline Маса тіла, кг & $23,2 \pm 0,14$ & $22,2 \pm 0,24$ & $+1,0$ & $\begin{array}{c}3,71 \\
(p<0,001)\end{array}$ & $21,6 \pm 0,35$ & $21,2 \pm 0,24$ & $+0,4$ & 0,94 \\
\hline $\begin{array}{l}\text { Обвід грудної } \\
\text { клітки, см }\end{array}$ & $58,8 \pm 0,49$ & $56,4 \pm 0,28$ & $+2,4$ & $\begin{array}{c}4,25 \\
(p<0,001)\end{array}$ & $57,9 \pm 0,41$ & $54,6 \pm 0,23$ & $+3,3$ & $\begin{array}{c}7,02 \\
(p<0,001)\end{array}$ \\
\hline
\end{tabular}


регіональних антропометричних критеріїв для дівчаток і хлопчиків різного віку.

ЛІТЕРАТУРА

1. Кучма В.Р. Теория и практика гигиены детей и подростков на рубеже тысячелетий. М. : изд-во Научного центра здоровья детей РАMН, 2001. 376 с.

2. Полька Н.С., Джуринська С.М., Яцковська Н.Я., Платонова А.Г. Сучасні тенденції фізичного розвитку міських дітей. Гігієна населених місць зб. наук. пр. К., 2009. Вип. 53. C. 299-303.

3. Полька Н.С., Платонова А.Г. До питання оцінки фізичного розвитку школярів за стандартами ВООЗ. Довкілля та здоров'я. 2012. № 1. С. 48-52.

4. Федоренко В.І., Штабський Б.М., Кіцула Л.М. Стан фізичного розвитку дітей дошкільного віку м. Львова та Львівської області (динаміка змін за 25 років). Вісник Вінницького державного медичного університету. 2003. № 2/2. С. 814-815.

5. Жигалина А.Х., Снигур О.Н., Василенко А.С. и др. Таблицы для оценки физического развития детей в возрасте от 1 года до 7 лет по материалам исследования детей, воспитывавшихся в яслях-садах г. Львова в 1969-1971 гг. Методические рекомендации для врачейпедиатров западных областей УССР). Львов, 1973. 26 с.

6. Штабський Б., Медчук І., Федоренко В. та ін. Стандарти фізичного розвитку дітей дошкільного віку: метод. рек. Львів, 1995. 16 с.

7. Штабський Б.М., Федоренко В.І., Кіцула Л.М., Павлів Р.І., Савченко Г.І. Стандарти фізичного розвитку дітей дошкільного віку м. Львова (19951996). Фізичний

Ступені фізичного розвитку 6-річних дітей (\%) м. за зростом (2014-2015)

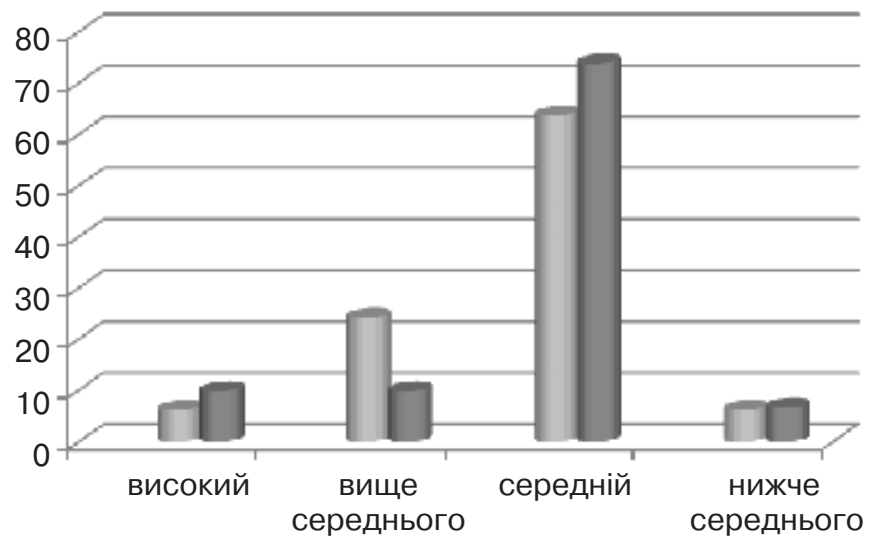

Practice of Children's and Teenagers' Hygiene at the Turn of Millenium]. Moscow ; 2001 : 376 p. (in Russian).

2. Polka N.S., Dzhurynska S.M., Yazkovska N.Ya. and Platonova A.G. Suchasni tendenzii fizychnoho rozvytku miskykh ditei [Modern Tendencies of Urban Children Physical Development]. In : Hihiiena naselenykh mists [Hygiene of Settlements] Kyiv; 2009 ; 53 : 299-303

(in Ukrainian).

3. Polka N.S. and Platonova A.G. Dovkillia ta zdorovia. $2012 ; 1$ : 48-52 (in Ukrainian).

4. Fedorenko V.I., Shtabskyi B.M. and Kitsula L.M. Visnyk Vinnytskoho derzhavnoho medychnoho universytetu. 2003 ; 2/2 : 814815 (in Ukrainian).

5. Zhygalina A.Kh., Snigur O.N., Vasilenko A.S. et al. Tablitsy dlia otsenki fizicheskogo razvitiia detey $v$ vozraste ot 1 goda do 7 let po materialam issledovaniia detey, vospityvavshykhsia $v$ yasliakh-sadakh g. Lvova v 1969-1971 gg. [Tables for Evaluation of Physical Development in the Children at the Age from 1 Year to 7 Years According to the Examination of the Children in the Day Nurseries - Kindergartens of the City of Lvov in 1969-1971]. In : Metodicheskiie rekomendatsii dlia vrachey-pediatrov zapadnykh oblastey USSR [ Methodical Recommendations for the Pediatricians of the Western Oblasts of the UkrSSR]. Lvov ; 1973 : 26 p. (in Russian).

6. Shtabskyi B., Medchuk I. Fedorenko V. et al. Standarty fizychnoho rozvytku ditei doshkilnoho viku : metodychni rekomendatsii [Standards of Physical Development of Pre-School Age Children: Method. Recom.]. Lviv ; 1995 : 16 p. (in Ukrainian).

7. Shtabskyi B.M., Fedorenko V.I., Kitsula L.M., Pavliv R.I. and Savchenko G.I. Standarty fizychnoho rozvytku ditei doshkilnoho viku $\mathrm{m}$. Lvova ta silskoi mistsevosti Lvivskoi oblas ti [Standards of Physical Development of Pre-School Age Children in the city of Lviv (19951996). Physical Development of Pre-School Age Children in the city of Lviv and Rural Area of the Lviv Oblast]. In : Fizychnyi rozvytok ditei riznykh rehioniv Ukrainy. Vyp. 2. Miski doshkilnyky [Physical Development of the Children in Different Regions of Ukraine. Issue 2. Urban Pre-

School Age Children]. Kyiv ; 2003

: 136-148 (in Ukrainian).

8. Moskviak N.V. Hihiienichna 
otsinka formuvannia adaptatsii shkoliariv molodshykh klasiv za umov navchannia u zahalnoosvitnomu zakladi na suchasnomu etapi [Hygienic Evaluation of the Formation of the Adaptation of Primary School Children under Conditions of Education at Comprehensive Educational Institution at Present Stage: Cand. Med. Sci., Abstract of Dis.]. Kyiv ; 2011 : 20 p. (in Ukrainian).

9. Hihiienichnyi normatyv "Kryterii otsinky fizychnoho rozvytku ditei shkilnoho viku" : Nakaz MOZ Ukrainy № 802 vid 13.09.2013. [Hygienic Standard "Criteria of the Assessment of Physical

Development of School Age Children" : Order of the Ministry of Public Health of Ukraine № 802, 13.09.2013] (in Ukrainian).

10. Fedorenko V.I., Kitsula L.M. Yakist kharchuvannia I fizychnyi rozvytok ditei [Quality of Nutrition and Physical Development of the Children]. In : Aktualni pytannia fiziolohii, patolohii ta orhanizatsii medychnoho zabezpechennia ditei shkilnoho viku ta pidlitkiv : aterially konf. [Current Issues of Physiology, Pathology, and Organization of Medical Provision of School-Age Children and Adolescents: Mater. Conf.]. Kharkiv ; 2013 ; 140-142 (in Ukrainian).

11. Hrachova T.I. Osoblyvosti fizychnoho rozvytku dytiachoho naselennia na suchasnomu etapi (na prykladi m. Chernivtsi) : avtoref. dys. Kand. Med. Nauk [Features of Physical Development of the Children's Population at Present Stage (by Way of Example of the city of Chernivtsi): Cand. Med. Sci., Abstract of Dis.]. Kyiv ; 2003 : 20 p. (in Ukrainian).

12. Ivakhno O.P. Sotsialno-hihiienichnyi monitorynh zdorovia dytiachoho naselennia Ukrainy u doshkilnomu vitsi [Social-andHygienic Monitoring of the Health of Children's Population of Ukraine at Pre-School Age]. In : Hihiiena naselenykh mists [Hygiene of Settlements]. Kyiv ; 2007 ; 50 : 296-299 (in

Ukrainian).

13. Platonova A.G. A.Г. Metodika skrining-otsenki fizicheskogo razvitiia detey po indeksu Ketle [Methodology of Screening-Assessment of Children's Physical Development by the Quetelet Index]. In : Hihiiena naselenykh mists [Hygien of Settlements]. Kyiv ; 2012 ; 60 : 356-362 (in Russian). Надійшла до редакції 17.02.2017
INFLUENCE OF PHYSICAL CULTURE AND SPORT ON THE INDICATORS OF PHYSICAL DEVELOPMENT IN THE SCHOOLCHILDREN Kapranov S.V. ВЛИЯНИЕ ЗАНЯтИЙ ФИЗКУЛЬТУРОЙ И СПОРТОМ
НА ПОКАЗАТЕИИ ФИЗИЧЕСКОГО РАЗВИтИЯ
ШКОЛЬНККОВ

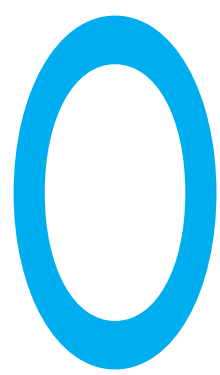

КАПРАНОВ С.В. Алчевский городской филиал ГУ «Луганский областной лабораторный центр Госсанэпидслужбы Украины»

УДК 613.4:371.72:796 (075.8)

Ключевые слова: физкультура и спорт, физическое развитие, школьники. беспечение высоких показателей здоровья детского населения является наиболее важной государственной и общественной проблемой. Согласно общепринятому определению, здоровье - это состояние полного физического, духовного и социального благополучия, а не только отсутствие болезни и физических дефектов. К одному из наиболее важных показателей здоровья традиционно относится физическое развитие. Под физическим развитием понимают «комплекс морфофункциональных свойств организма, который определяет запас его физических сил». Применительно к детям понятие физического развития расширяется и прежде всего включает в себя соотнесение комплекса морфофункциональных свойств с возрастом биологического развития ребенка [1].

В результате исследований установлено, что в течение последних пятидесяти лет

ВПЛИВ ЗАНЯТТЯ ФІЗКУЛЬТУРОЮ ТА СПОРТОМ НА ПОКАЗНИКИ ФІЗИЧНОГО РОЗВИТКУ ШКОЛЯРІВ

Капранов С.В.

Алчевська міська філія Ду "Луганський обласний лабораторний центр Держсанепідслужби України"

Провідним фактором формування фізичного розвитку та інших показників здоров'я дитячого населення $\epsilon$ фізична активність, основними проявами якої визначено фізичну культуру та спорт. Мета роботи. Вивчення впливу занять фізкультурою та спортом на показники фізичного розвитку школярів.

Матеріали і методи. З метою оцінки фізичного розвитку 1399 учнів віком 13-17 років проведено антропометричні дослідження довжини тіла, маси тіла та обводу грудної клітки. Оцінку отриманих даних виконано за статево-віковими шкалами регресії та центильним методом.

Результати. Встановлено, що $(31,45 \pm 1,24) \%$ учнів середніх загальноосвітніх шкіл не займалися ранковою гімнастикою (фізичною зарядкою), $(38,46 \pm 1,30) \%$ не займалися спортом, пов'язаним з фізичним навантаженням. Дівчат, які регулярно займалися гімнастикою та спортом, у 2,2 рази і 1,6 рази відповідно було менше порівняно з хлопцями. Відмова школярів від регулярних занять фізичними вправами є фактором ризику дисгармонійності їхнього фізичного развитку, що формується передусім за рахунок дефіциту обводу грудної клітки та маси тіла. Запропоновано рекомендації щодо поліпшення фізичного розвитку учнів.

Ключові слова: фізкультура та спорт, фізичний розвиток, школярі.

ㄷ Капранов С.В. СТАТТЯ, 2017. 